\title{
YIELD AND YIELD ATTRIBUTES OF OKRA AS INFLUENCED BY PLANTING TIME AND PLANT SPACING IN HILL SLOPE CONDITION
}

\author{
Z. A. Firoz, M. A. Islam, M. Mohiuddin and M. M. Rahman \\ Regional Agricultural Research Station, Hathazari, Chittagong, Bangladesh
}

\begin{abstract}
An experiment was conducted at the Hill Agricultural Research Station, Khagrachari from May to November 2004 to find out the effect of planting time ( $1^{\text {st }}$ week of June, July, August and September) and plant spacing $(60 \times$ $30 \mathrm{~cm}, 60 \times 40 \mathrm{~cm}$ and $60 \times 50 \mathrm{~cm}$ ) on the yield and yield components of okra in hill slope condition during rainy season. The highest yield (12.53 t/ha) was obtained by the planting in July which was at par with June (11.69 t/ha). In case of plant spacing, the highest yield (9.02 t/ha) was recorded from close spacing at $60 \times 30 \mathrm{~cm}$ that was statistically different from other two spacing and the widest spacing of $60 \times 50 \mathrm{~cm}$ produced the lowest yield $(8.06$ $\mathrm{t} / \mathrm{ha}$ ). The treatment combination July sowing with $60 \times 30 \mathrm{~cm}$ plant spacing produced significantly highest yield (12.86 t/ha).
\end{abstract}

Key Words : Hill slope, Okra yield, Planting time, Plant spacing

\section{INTRODUCTION}

Okra [Abelmoschus esculentus (L.) Moench] is an annual vegetable crop in tropical and sub-tropical parts of the world (Thakur and Arora, 1986). It is one of the important nutritious vegetable crops grown round the year in Bangladesh. Vegetable availability in Bangladesh is primarily concentrated in the winter season. The shortage of vegetables prevails from June to September (rainy season) due to lower production. Of the total vegetable production, around $70 \%$ is produced during rabi season and the rest $30 \%$ in kharif season (Hossain, 1992). There is crucial need to increase vegetable production during rainy season through proper management techniques or introducing new rainy season vegetables. Okra as a summer/ rainy season vegetable can play a vital role in this regard. Chittagong Hill tracts region is about one tenth of the total area of Bangladesh (Anon, 1985). This area has great potentiality for growing okra during rainy season when the major part of the country goes under water by using high yielding varieties with improved production practices.

The sowing time plays an important role on yield of okra fruit and seed. Okra production in Bangladesh is mainly limited from February to July (Rashid, 1995). But its production from July onwards or even in winter is possible provided the vegetative growth of Plant is completed before the temperature falls and some diseases can be controlled (Islam, 1997). The production of okra in off-season may meet up the market demand during the lean period of vegetable supply and can improve the nutritional status. The effect of planting time on the growth and yield of okra was reported by many authors (DizFranco and Ortigon, 1997; Passam et al., 1998; Amzad et al., 2001). 
Plant spacing is an important factor for okra production both in summer and rainy season crop (Palanisamy et al., 1986; Shaha et al., 1989; Saimbhi et al., 1997; Hossain et al., 1999). The improper plant spacing may cause either too dense or too sparse population resulting in the reduction of okra yield. But optimum plant density ensures the plants to grow uniformly and properly through efficient utilization of moisture, nutrients, light and thus causes to produce maximum yield of okra. Planting with proper spacing increases yield quality and size of fruit. In hilly region of Bangladesh systematic and comprehensive research effort on planting time and plant spacing in order to increase yield potential of okra is inadequate or sporadic. Considering this an experiment was carried out to determine the appropriate planting time and plant spacing for okra production in hill slope.

\section{MATERIALS AND METHODS}

The experiment was conducted at the Hill Agricultural Research Station, Khagrachari from May to November 2004. The experiment was laid out in a factorial combination in RCBD with three replications. The treatments of the experiment were four planting times viz. $1^{\text {st }}$ week of June, July, August and September and three plant spacing viz. $60 \times 30,60$ $\times 40$ and $60 \times 50 \mathrm{~cm}$. Thus, altogether there were 12 treatments combinations. The okra variety was BARI Dherosh-1 The unit plot size was $6.0 \times 1.8 \mathrm{~m}$. The plot and blocks were separated by 0.5 and $1.0 \mathrm{~m}$, respectively. Each unit plot had 3 rows. Fertilizers were used at the rate of 150, 100 and $150 \mathrm{t} /$ ha of Urea, TSP and MP, respectively. Cowdung was used @10 t/ha during land preparation. Intercultural operations were done as and when necessary. Harvesting was started from 15 July and continued up to 30 November 2004. Data on yield contributing characters were recorded from ten randomly selected plants. Collected data were subjected to statistical analysis by F-test and the difference among the treatment means were judged by Duncan's Multiple Range Test (DMRT).

\section{RESULTS AND DISCUSSION}

\section{Number of fruits per plant}

Number of fruits per plant is no doubt an important component. Higher the number of fruits per plant, higher the yield. However, size and weight of individual fruit can modify the statement to a great extent. Whatever the fact, the general consent is in favour of grater number of fruits per plant. The number of fruits per plant was significant reduced with the delay in sowing dates (Table 1). The maximum number of fruits per plant was obtained from July sowing (18.1). This was statistically followed by June sowing (17.4). Beyond July there was reduction in number of fruits per plant. The number of fruits per plant in the crop of September was the lowest (6.1) and it significantly differed with August sowing (11.8). As the plant growth condition was not satisfactory in delay sowing crops, the number of fruits per plant was also reduced. This result is in agreement with the finding of Grewal et al. (1972) who mentioned that number of fruits declined at later sowing dates from July to on ward. Hossain et al. (1999) and Islam (1997) also found that the number of fruits per plant was higher in summer and rainy seasons than that of winter season. However, Yadav and Dhankhan (1999) stated that sowing on 13 June resulted lower number of fruits per plant. 
Table 1. Yield and yield components of okra as influenced by planting time and plant spacing

\begin{tabular}{|c|c|c|c|c|c|}
\hline Treatment & $\begin{array}{c}\text { No. of } \\
\text { fruits/plant }\end{array}$ & $\begin{array}{l}\text { Fruit length } \\
(\mathrm{cm})\end{array}$ & \begin{tabular}{|c|} 
Fruit diameter \\
$(\mathrm{cm})$
\end{tabular} & $\begin{array}{l}\text { Individual } \\
\text { fruit wt. (g) }\end{array}$ & $\begin{array}{c}\text { Wt. of } \\
\text { fruits/plant (g) }\end{array}$ \\
\hline \multicolumn{6}{|l|}{ Planting time } \\
\hline $1^{\text {st }}$ week of June & $17.4 \mathrm{a}$ & $14.3 \mathrm{~b}$ & $1.64 \mathrm{a}$ & $13.4 \mathrm{a}$ & $232.8 \mathrm{a}$ \\
\hline $1^{\text {st }}$ week of July & $18.1 \mathrm{a}$ & $15.1 \mathrm{a}$ & $1.65 \mathrm{a}$ & $13.5 \mathrm{a}$ & $246.4 \mathrm{a}$ \\
\hline $1^{\text {st }}$ week of August & $11.8 \mathrm{~b}$ & $14.4 \mathrm{~b}$ & $1.54 \mathrm{~b}$ & $10.8 \mathrm{~b}$ & $229.3 \mathrm{~b}$ \\
\hline $1^{\text {st }}$ week of September & $6.1 \mathrm{c}$ & $9.9 \mathrm{c}$ & $1.44 \mathrm{c}$ & $8.8 \mathrm{c}$ & $61.2 \mathrm{c}$ \\
\hline \multicolumn{6}{|l|}{ Plant spacing } \\
\hline $60 \times 30 \mathrm{~cm}$ & $11.3 \mathrm{c}$ & 11.9 & $1.54 \mathrm{~b}$ & $106 \mathrm{~b}$ & $136.9 \mathrm{~b}$ \\
\hline $60 \times 40 \mathrm{~cm}$ & $13.1 \mathrm{~b}$ & 12.2 & $1.57 \mathrm{~b}$ & $11.0 \mathrm{a}$ & $162.7 \mathrm{~b}$ \\
\hline $60 \times 50 \mathrm{~cm}$ & $15.7 \mathrm{a}$ & 12.6 & $1.61 \mathrm{a}$ & $11.1 \mathrm{a}$ & $202.7 \mathrm{a}$ \\
\hline
\end{tabular}

Means followed by a common letter or no letter are not significantly different at $5 \%$ level by DMRT

Significant difference was noticed on number of edible fruits per plant due to spacing (Table 1). The highest number of fruits per plant (15.7) was obtained with the spacing of $60 \times 50 \mathrm{~cm}$ which showed significant variation with other two spacing while the lowest (6.1) number of fruits per plant was produced by $60 \times 30 \mathrm{~cm}$. Palanisamy et al. (1986) and Abdul and Araf (1986) also stated that wider spacing slightly increased number fruits/plant. Reduced number of plants per unit area under wider spacing got less inter and intra plant competition which caused an increased number of fruits per plant.

So far as the interaction (Table 2) between planting time and plant spacing is concerned, the plant in July sowing coupled with $60 \times 50 \mathrm{~cm}$ spacing $\left(\mathrm{T}_{2} \mathrm{~S}_{3}\right)$ gave the most satisfactory result (22.5 fruits/ plant) and it was statistically identical to June sowing with $60 \times 50 \mathrm{~cm}$ spacing $\left(\mathrm{T}_{1} \mathrm{~S}_{3}\right)$. The second highest number of fruits per plant (17.4) was obtained when plants was treated with $\mathrm{T}_{2} \mathrm{~S}_{2}$. This was statistically followed by those with $\mathrm{T}_{2} \mathrm{~S}_{3}$ (14.4), $\mathrm{T}_{1} \mathrm{~S}_{1}$ (14.5) and $\mathrm{T}_{1} \mathrm{~S}_{2}$ (14.5). September sowing with $60 \times 30 \mathrm{~cm}\left(\mathrm{~T}_{4} \mathrm{~S}_{1}\right)$ produced the least number (5.1) of fruits and this was at par with $\mathrm{T}_{4} \mathrm{~S}_{2}(6.2)$ and $\mathrm{T}_{4} \mathrm{~S}_{3}$ (6.8). But Sajjan et al. (2002) got the highest number of fruits per plant from sowing on 15 July with $60 \times 30$ $\mathrm{cm}$ spacing. This result partially supported the present result.

\section{Fruit size}

Fruits of July sowing were observed larger than those of other dates of sowing (Table 1). Significantly highest fruits length $(15.2 \mathrm{~cm})$ was noticed in July sowing as compared to those obtained from June, August and September sowing plants. There was no significant difference between August and September sowing. Fruit diameter was also highest $(1.65 \mathrm{~cm})$ in July sowing but it was at par with June sowing $(1.64 \mathrm{~cm})$.

The plants at the spacing $60 \times 30 \mathrm{~cm}$ produced fruits having the largest length of $13.8 \mathrm{~cm}$ (Table 1) which was statistically different from fruit length of the plants at $60 \times 40$ and $(13.0 \mathrm{~cm})$ and $60 \times 30 \mathrm{~cm}(13.1 \mathrm{~cm})$ spacing. The larger fruits at widest spacing might be due to the accumulation of more dry matter by the plants. This result is accordance with 
that of Palanisamy et al. (1986). They found that fruit length increased with decreasing of plant density. Fruit diameter also showed similar trend (Table 1). No significant difference was found due to the interaction effect of plant time and plant spacing in this regard (Table 2).

Table 2. Interaction effects of planting time and plant spacing on the yield and yield components of okra

\begin{tabular}{l|c|c|c|c|c}
\hline Treatment & $\begin{array}{c}\text { No. of } \\
\text { fruits/plant }\end{array}$ & $\begin{array}{c}\text { Fruit length } \\
(\mathrm{cm})\end{array}$ & $\begin{array}{c}\text { Fruit diameter } \\
(\mathrm{cm})\end{array}$ & $\begin{array}{c}\text { Individual } \\
\text { fruit wt. }(\mathrm{g})\end{array}$ & $\begin{array}{c}\text { Wt. of } \\
\text { fruits/plant (g) }\end{array}$ \\
\hline $\mathrm{T}_{1} \mathrm{~S}_{1}$ & $14.5 \mathrm{bc}$ & $13.6 \mathrm{~b}$ & 1.62 & 13.3 & $192.5 \mathrm{bc}$ \\
$\mathrm{T}_{1} \mathrm{~S}_{2}$ & $16.8 \mathrm{~b}$ & $14.3 \mathrm{ab}$ & 1.63 & 13.3 & $220.5 \mathrm{~b}$ \\
$\mathrm{~T}_{1} \mathrm{~S}_{3}$ & $21.0 \mathrm{a}$ & $14.9 \mathrm{a}$ & 1.68 & 13.6 & $285.4 \mathrm{a}$ \\
$\mathrm{T}_{2} \mathrm{~S}_{1}$ & $14.4 \mathrm{bc}$ & $14.7 \mathrm{ab}$ & 1.59 & 13.1 & $194.9 \mathrm{~b}$ \\
$\mathrm{~T}_{2} \mathrm{~S}_{2}$ & $17.4 \mathrm{~b}$ & $15.2 \mathrm{a}$ & 1.65 & 13.5 & $234.9 \mathrm{~b}$ \\
$\mathrm{~T}_{2} \mathrm{~S}_{3}$ & $22.5 \mathrm{a}$ & $15.6 \mathrm{a}$ & 1.71 & 13.7 & $309.3 \mathrm{a}$ \\
$\mathrm{T}_{3} \mathrm{~S}_{1}$ & $10.8 \mathrm{~d}$ & $10.8 \mathrm{c}$ & 1.52 & 10.4 & $111.7 \mathrm{~d}$ \\
$\mathrm{~T}_{3} \mathrm{~S}_{2}$ & $12.1 \mathrm{~cd}$ & $11.6 \mathrm{bc}$ & 1.54 & 10.8 & $130.0 \mathrm{c}$ \\
$\mathrm{T}_{3} \mathrm{~S}_{3}$ & $12.6 \mathrm{~cd}$ & $11.7 \mathrm{abc}$ & 1.57 & 11.1 & $146.3 \mathrm{c}$ \\
$\mathrm{T}_{4} \mathrm{~S}_{1}$ & $5.2 \mathrm{e}$ & $7.6 \mathrm{~d}$ & 1.41 & 8.3 & $48.5 \mathrm{e}$ \\
$\mathrm{T}_{4} \mathrm{~S}_{2}$ & $6.2 \mathrm{e}$ & $8.0 \mathrm{~d}$ & 1.43 & 9.1 & $63.5 \mathrm{e}$ \\
$\mathrm{T}_{4} \mathrm{~S}_{3}$ & $6.8 \mathrm{e}$ & $8.1 \mathrm{~d}$ & 1.47 & 9.3 & $69.6 \mathrm{e}$ \\
\hline $\mathrm{CV}(\%)$ & 13.7 & 3.2 & 5.54 & 2.86 & 12.1 \\
\hline
\end{tabular}

Means followed by a common letter or no letter are not significantly different at $5 \%$ level by DMRT.

$\mathrm{T}_{1}=1^{\text {st }}$ week of June, $\mathrm{T}_{2}=1^{\text {st }}$ week of July, $\mathrm{T}_{3}=1^{\text {st }}$ week of August, $\mathrm{T}_{4}=1^{\text {st }}$ week of September; $\mathrm{S}_{1}=60 \times 30 \mathrm{~cm}, \mathrm{~S}_{2}=60 \times 40 \mathrm{~cm}, \mathrm{~S}_{3}=60 \times 50 \mathrm{~cm}$

\section{Individual fruit weight}

It is not only the number of fruits per plant but individual fruit weight also plays a key role in determining yield per plant or per unit land. Planting time showed significant effect of individual fruit weight as presented in Table 1. The heaviest (13.5 g) fruit weight was attained from July sowing followed by June sowing $(13.4 \mathrm{~g})$ and it was gradually reduced in the crop of August (10.8 g) and September sowing (9.8 g).

Significant difference in fresh fruit weight at edible stage was observed due to differences in spacing (Table 1). The highest $(13.1 \mathrm{~g})$ was recorded from the widest spacing at $60 \times 50$ $\mathrm{cm}$ and minimum fruit weight was obtained from the plants in closer spacing at $60 \times 30$ $\mathrm{cm}(11.6 \mathrm{~g})$. The planting times insignificantly interacted with the spacing (Table 2).

\section{Fruit yield per plant}

Yield capacity of okra is the function of number of okra per unit area, number of fruits per plant and fruit size. Table 1 revealed that the highest $(246.4 \mathrm{~g})$ fruit yield per plant was obtained from plants of July sowing which was statistically followed by June sowing $(232.8 \mathrm{~g} /$ plant). The lowest $(61.2 \mathrm{~g})$ production was recorded in September sowing. The 
poor vegetative growth i.e. plant height, branch per plant and decreased number of fruits per plant in delay sowing resulted in lower yield per plant reduction.

Fruits yield per plant varied widely among the three-plant spacing (Table 2). Plants of 60 x $50 \mathrm{~cm}$ spacing produced significantly higher amount of fruits $(202.7 \mathrm{~g})$ per plant as compared to those produced by other treatments. Similar result was also reported by Shaha et al. (1989); Rehman et al. (1994).

The responses of planting time and plant spacing interaction was significant in weight of fruits per plant (Table 2). Weight of fruits per plant showed a similar pattern with number of fruits per plant. The June and July sowing with $60 \times 50$ plant spacing $\left(\mathrm{T}_{2} \mathrm{~S}_{3}\right.$ and $\mathrm{T}_{1} \mathrm{~S}_{3}$, respectively) had considerably better performance (309.3 $\mathrm{g}$ and $285.9 \mathrm{~g}$ ) compared to the other treatments.

\section{Yield ( $t / h a)$}

Okra production due to planting time is found to differ significantly and is presented in Fig. 1. The most satisfactory yield (12.53 $\mathrm{t} / \mathrm{ha}$ ) was produced by the plants of July sowing was at par with June (11.69 t/ha). Fruit yield of okra was extremely poor in the crop of September sowing $(3.09 \mathrm{t} / \mathrm{ha}$ ) which indicated that okra cultivated in late rainy season in hill slope condition might be affected adversely by low rainfall and little bit cool weather at fruiting stage (Islam, 1997). The lowest number of fruits and weight of fruits per plant in delay sowing resulted in total yield reduction. Gadakh et al. (1990) reported that among the autumn, winter and summer, the crop gave the lowest yield in winter. Similarly, the yield of BARI Dherosh-1 was gradually decreased from summer to winter (Anon, 1997) and July on ward (Islam, 1997). Satpathy et al. (1985) reported that maximum yield was obtained from the crop sown in first week of June.

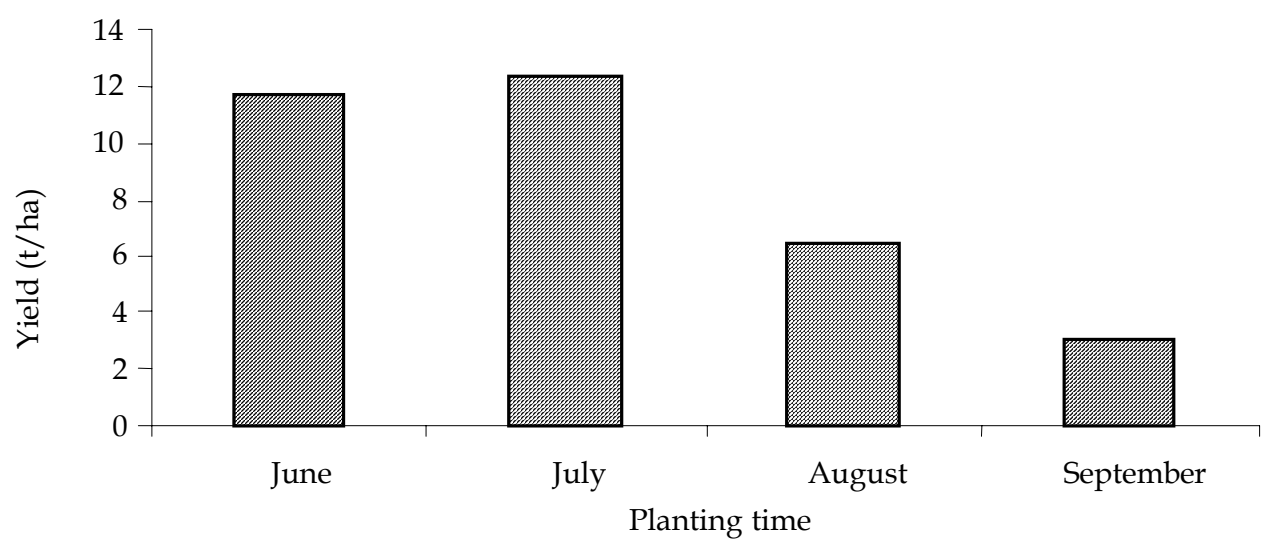

Fig. 1. Main effect of planting time on fruit yield of okra

The most satisfactory $(9.02 \mathrm{t} / \mathrm{ha})$ per hectare yield was recorded from close spacing at 60 x $30 \mathrm{~cm}$ which was statistically different from other two spacings and the widest spacing of $60 \times 50 \mathrm{~cm}$ produced the lowest yield (8.06 t/ha) (Fig. 1). The result indicated that fruit 
production (t/ha) increased with the decrease in plant spacing. Khan and Jaisal (1988), Mondal et al. (1989) and Singh et al. (1988) reported higher yield of okra per hectare at closer spacing (Fig. 2). Increase in fruit yield at closer spacing could be attributed to higher number of plant per unit urea.

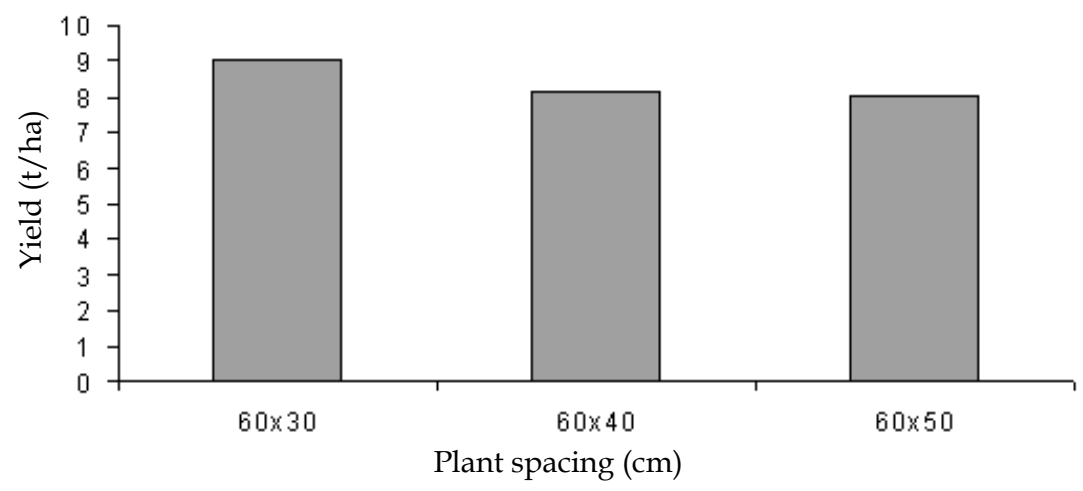

Fig. 2. Main effect of plant spacing on fruit yield of okra

The interaction effect of sowing time and plant spacing on edible fruit yield is presented in Fig. 3. The treatment combination July with $60 \times 30 \mathrm{~cm}$ produced significantly highest (12.86 t/ha) yield followed by June with $60 \times 30 \mathrm{~cm}(12.63 \mathrm{t} / \mathrm{ha})$, July with $60 \times 50 \mathrm{~cm}$ $(12.37 \mathrm{t} / \mathrm{ha})$ and July with $60 \times 40 \mathrm{~cm}(11.75 \mathrm{t} / \mathrm{ha})$. Identically poor yield were produced by September with $60 \times 30 \mathrm{~cm}(3.20 \mathrm{t} / \mathrm{ha})$, September with $60 \times 40 \mathrm{~cm}(3.27 \mathrm{t} / \mathrm{ha})$ and September with $60 \times 50 \mathrm{~cm}(2.8 \mathrm{t} / \mathrm{ha})$.

The above result revealed that July sowing with $60 \times 30 \mathrm{~cm}$ plant spacing is most suitable for better production of okra in hill slope condition.

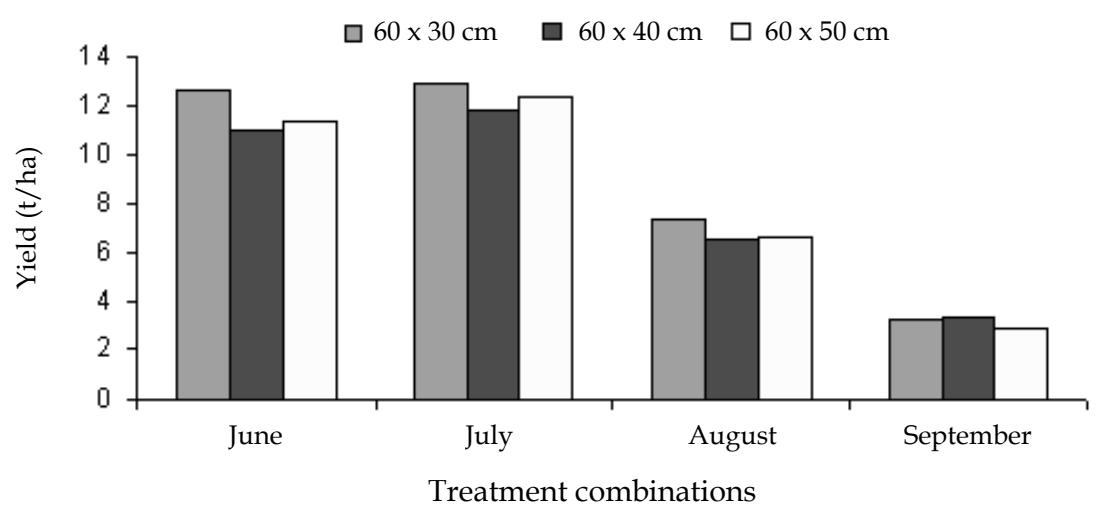

Fig. 3. Interaction effect of planting time and plant spacing on fruit yield ( $t /$ ha) of okra

\section{REFERENCES}

Abdul, K. S. and Arafk, L. S. 1986. Effect of plant spacing and fertilizer on the growth and yield of okra. Iraq J. Agril. Sci., 4(2) : 77-89. 
Amzad, M., Anzum, M. A. and Sajid Hossain. 2001. Effect of different sowing dates and various doses of fertilizers of juvenility and productivity of okra. Pakistan J. Agril. Sci., 38(1 \& 2) : 29-32.

Anonymous. 1997. Annual Report. Regional Agril. Res. Station, Barisal, Bangladesh.

Anonymous, 1985, The Year Book of Agricultural Statistics of Bangladesh. Bangladesh Bureau of Statistics Ministry of Planning Dhaka.

Diz-Franco, A. and A. S. Ortegon. 1997. Influence on the production of okra (Abelmoschus esculentus L. Moench) cultivars. Agronomia Meroamerieana, 8(1) : 93-98 .

Gadakh, S. R., K.E. Lawande and P. N. Kale. 1990. Effect of different seasons and spacing on yield and quality of bhendi. Harayana J. Hort. Sci., 19(3-4) : 329-332

Grewal, B. S., K. S. Nanpuri and J. C. Kumar. 1972. Effect of sowing dates, spacing and picking of green pods on yield and quality of okra seed. Punjab Hort. J., 13(4) : 247-252.

Hossain, M. D., M. A. Salam, M. S. Islam and M. A. T. Masud. 1999. Yield and quality of okra (BARI Dherosh-1) Seed as influenced by time of sowing and plant spacing. Bangladesh J. Seed Sci. Tech., 3(1 \& 2) : 83-87.

Hossain, S. M. 1992. Status, constrains and strategies of vegetable research. In : Katherine and Eli. L (eds.). Vegetable production and marketing. Proceedings of a national review and planning Workshop held at BARI , Gazipur, Bangladesh. 26-29 January. 1992 p. 31.

Islam , M. S. 1997. Off-season performance of okra for vegetable and seed production. M. S. Thesis, Institute of Postgraduate Studies in Agriculture (IPSA), Gazipur, Bangladesh.

Khan, A. R. and Jaisal, R. C. 1988. Effect of nitrogen, spacing and green fruit pickings on the seed production of okra (Abelmoschus esculentus L. Moench). Vegetable Science, 15(1) : 8-14.

Mondal, G., S. C. Malik and T. K. Maity. 1989. Effects of sowing date and spacing on the growth and yield of okra. Crop research Hisar, 2(2) : 230-231.

Palanisamy, V., K. Vanangamudi, T. Joyaroj and T. V. Karivarattaraju. 1986. Influence of data of sowing and spacing on seed quality in bhindi. South Indian Hort., 34(1) : 23-25.

Passam, H. C., Akouminakis, A. and Sarigiannidi, A. 1998. The effect of time of sowing on the production of okra (Hibiscus esculentus L.) seed in the Mediterranean region. Plant Varieties Seeds, 11(3) : 145-150.

Rashid, M. M. 1995. Sabji Bingan (in Bengali). Bangla Academy. Dhaka. Bangladesh. p. 467.

Rehman, K., Khan, S., Mohammad, N., Ibrahim, M. and Haq, I. 1994. Effect of different nitrogen levels and spacing on growth and yield of okra. Sarhad J. Agric., 10(2) : 165-167.

Saimbhi, M. S., Datgit Singh, Sandhu, K. H., Kooner, K. S., Phillon, N. P. S. and Singh, D. 1997. Effect of plant spacing on fruit-yield of okra. Agricultural Sciences Digest karnal, 17(1) : 40-42.

Sajjan, A. S., Shekhengouda, M. and Badanur, V. P. 2002. Influence of date of sowing, spacing and level of nitrogen on yield attributes and seed yield of okra. Karnataka J. Agric. Sci., 15(2) : 267-274.

Satpathy, S., Samarjeet Rai and Rai, S. 1998. Influence of sowing date, and crop phenology on pest infestation in okra. Veg. Sci., 25(2) : 178-180.

Shaha, P. K., Aditya, D. K. and Sharf Uddin, A. F. M. 1989. Effects of plant spacing and picking interval on the growth and yield of okra cv. Pusa Sawani. Bangladesh Hort., 17(2) : 0-14.

Singh, K., Saraik, D. A. and Bisen, C. S. 1988. Effect of sowing dates and spacing on the yield and quality of okra seed (Abelmoschus esculentus L. Moench). Res. Dev. Rep., 5(1-2) : 83-86.

Thakur, M. R. and Arora, S. K. 1986. Okra, In : Bose, T. K. and M. G. Som (ed) Vegetable Crops in India. Naya Prokash, Calcutta. pp. 610-618.

Yadav, S. K. and B. S. Dhankar. 1999. Performance of Varsha Uphan cultivar of okra [Abelmoschus esculenttus (L). Moench] as affected by sowing dates and plant geometry. Vegetable Science, 26(2) : 180-182. 